\title{
Beyond Group Ranch Subdivision: Collective Action for Livestock Mobility, Ecological Viability, and Livelihoods
}

\author{
Shauna BurnSilver, Natural Resource Ecology Laboratory, \\ Colorado State University and \\ Esther Mwangi \\ International Food Policy Research Institute
}

The CGIAR Systemwide Program on Collective Action and Property Rights (CAPRi) is an initiative of the 15 centers that belong to the Consultative Group on International Agricultural Research. The initiative promotes comparative research on the role played by property rights and collective action institutions in shaping the efficiency, sustainability, and equity of natural resource systems. CAPRi's Secretariat is hosted by the International Food Policy Research Institute's (IFPRI) Environment and Production Technology Division (www.ifpri.org).

CAPRi Working Papers contain preliminary material and research results and are circulated prior to a full peer review in order to stimulate discussion and critical comment. It is expected that most Working Papers will eventually be published in some other form, and that their content may also be revised. http://dx.doi.org/10.2499/CAPRiWP66.

Copyright @ June 7, 2007 International Food Policy Research Institute. All rights reserved. Sections of this material may be reproduced for personal and not-for-profit use without the express written permission of but with acknowledgment to IFPRI. To reproduce the material contained herein for profit or commercial use requires express written permission. To obtain permission to reprint, contact the IFPRI Communications Division at ifpri-copyright@cgiar.org.

CGIAR Systemwide Program on Collective Action and Property Rights (CAPRi) c/o INTERNATIONAL FOOD POLICY RESEARCH INSTITUTE

2033 K Street NW, Washington, DC 20006-1002 USA • T +1 202.862.5600 • F +1 202.467.4439 • www.capri.cgiar.org 


\section{ACKNOWLEDGEMENTS}

We would like to thank the Maasai of Central and Southern Kajiado who have spent endless time speaking with us and relating their stories during this crucial time of transition. Our field research assistants were also critical in this work. Our sincere thank yous to:

Timothy Tonkei, Peter Ndirangu, Lucas Anduga, Richard Solonga Supeet, and Justus Lekimankusi Supeet. The work of Randall Boone was instrumental in the NDVI analyses; he also created maps of the study areas and provided valuable comments on the paper. We also thank Elliot Fratkin and Helen Markelova for their useful comments. BurnSilver's fieldwork was supported by the Global Livestock CRSP (Collaborative Research Support Program of the office of Agriculture and Food Security Global Bureau USAID under grant no. PCE-G-98-0036-000), a supplementary research grant from ILRI (thank you to P. Kristjanson), and the ILRI Ereto-OEreto project supported by the Belgian Ministry of Foreign Affairs, Foreign Trade and International Co-operation under their program for Belgian Support of International Agricultural Research for Development. Mwangi's fieldwork was supported by the National Science Foundation, the Comptom Foundation, the Institute for the Study of World Politics, and the Association of American University Women. 


\begin{abstract}
This paper leverages datasets and results from two separate studies carried out across eight Kajiado group ranches and offers a unique opportunity to look at emergent pre- and postsubdivision trends from an interdisciplinary framework that combines ecological, political, and human-ecological research perspectives. It provides insights into the following issues: the loss of flexibility and mobility for Maasai herders' dues to subdivision, the nature of collective activities that individuals pursue after subdivision, and the emergence of pasture sharing arrangements. NDVI profiles show that forage options for individual herders decrease dramatically under privatization, but rebound somewhat when parcels are shared between households located adjacent to each other. Interviews show that households redistribute portions of their herds for long periods and swap/share pastures. Parcel sharing translates into more grazing flexibility, particularly when it occurs between households in different locations. The Maasai also continue to develop and finance collective structures for the provision and maintenance of boreholes, earthen dams, schools and health clinics. Although new economic innovation characterizes some of these strategies, most are grounded within traditional social networking mores. There is need for policy makers to support these efforts as they evolve.
\end{abstract}

Keywords: Kajiado, group ranches, subdivision, collective action, pastoralism, flexibility, mobility 


\section{TABLE OF CONTENTS}

$\begin{array}{ll}\text { Introduction } & 1\end{array}$

$\begin{array}{ll}\text { Results } & 16\end{array}$

$\begin{array}{ll}\text { Discussion } & 29\end{array}$

$\begin{array}{ll}\text { References } & 37\end{array}$ 


\title{
Beyond Group Ranch Subdivision: Collective Action for Livestock Mobility, Ecological Viability and Livelihoods
}

\author{
Shauna BurnSilver ${ }^{1}$ and Esther Mwangi ${ }^{2}$
}

\section{INTRODUCTION}

Pastoralism is the dominant land use in 25 percent of the world's landscapes and comprises the basic subsistence strategy of 20 million households (Galaty and Johnson 1990). These rangeland ecosystems largely occur in regions too dry for rainfed agriculture and are characterized by recurrent drought and strong intra- and inter-seasonal variability in climate (Ellis and Galvin 1994, Galvin et al. 2001). Historically, the primary pastoral response to minimize risk has been mobility. Opportunistic and extensive seasonal livestock movements provided access to water and forage resources that were heterogeneous (i.e. patchy) in space and time. This mobility occurred largely in the context of communal land tenure systems - wherein flexible use rights were negotiated through layered memberships in kinship, clan, and lineage groupings (Bekure et al. 1991, Lane and Moorehead 1994, Turner 1999). Recent developments in ecological and common property theories clearly support the logic of pastoral mobility to compensate for resource heterogeneity (Ellis and Swift 1988, Ostrom et al. 1999, Illius and O’Connor 2000). However, over the past three decades, a combination of government policy and internal drivers has pushed pastoral systems in the opposite direction, towards privatization of communal rangelands characterized by little flexibility (Galaty 1992, Niamir-Fuller 1999, Blench 2001). Many scientists are concerned that this transition from mobile systems to

\footnotetext{
${ }^{1}$ Natural Resource Ecology Laboratory, Colorado State University

2 International Food Policy Research Institute, CGIAR Systemwide Program on Collective Action and Property Rights (CAPRi)
} 
continuous grazing of private parcels will lead to ecological degradation and spiraling poverty among pastoral households, and a gradual decrease in both system stability and sustainability (Ellis et al. 2001, Agrawal 2002, Reid et al. 2003, Boone and Hobbs 2004).

Pastoral producers in East Africa face a critical dilemma. They are caught between new land tenure rules associated with the dissolution of group ranches and subdivision of communal rangelands, and the unchanged ecological exigencies of their dryland systems. Poverty among East African pastoral households is generally high (Thornton et al. 2003), and research over the last three decades indicates a steady decline in tropical livestock units per capita in pastoral areas (Bekure et al. 1991, Rutten 1992) with a growing divide between wealthy and poorer pastoralists (Fratkin and Mearns 2003). Rising poverty and the trajectory of pastoral systems towards increasing privatization and fragmentation begs the question: What is next? The Maasai of Kajiado District, Kenya offer a strong example of a pastoral group in the midst of the economic and socio-political transitions that accompany the shift from communal land use to private ownership.

According to official records in 2006, out of a total of 52 group ranches, 32 are subdivided, and 15 are in progress, seven of which are disputed and under court injunction (Figure 1). 


\section{Figure 1--Subdivision status of group ranches in Kajiado district}

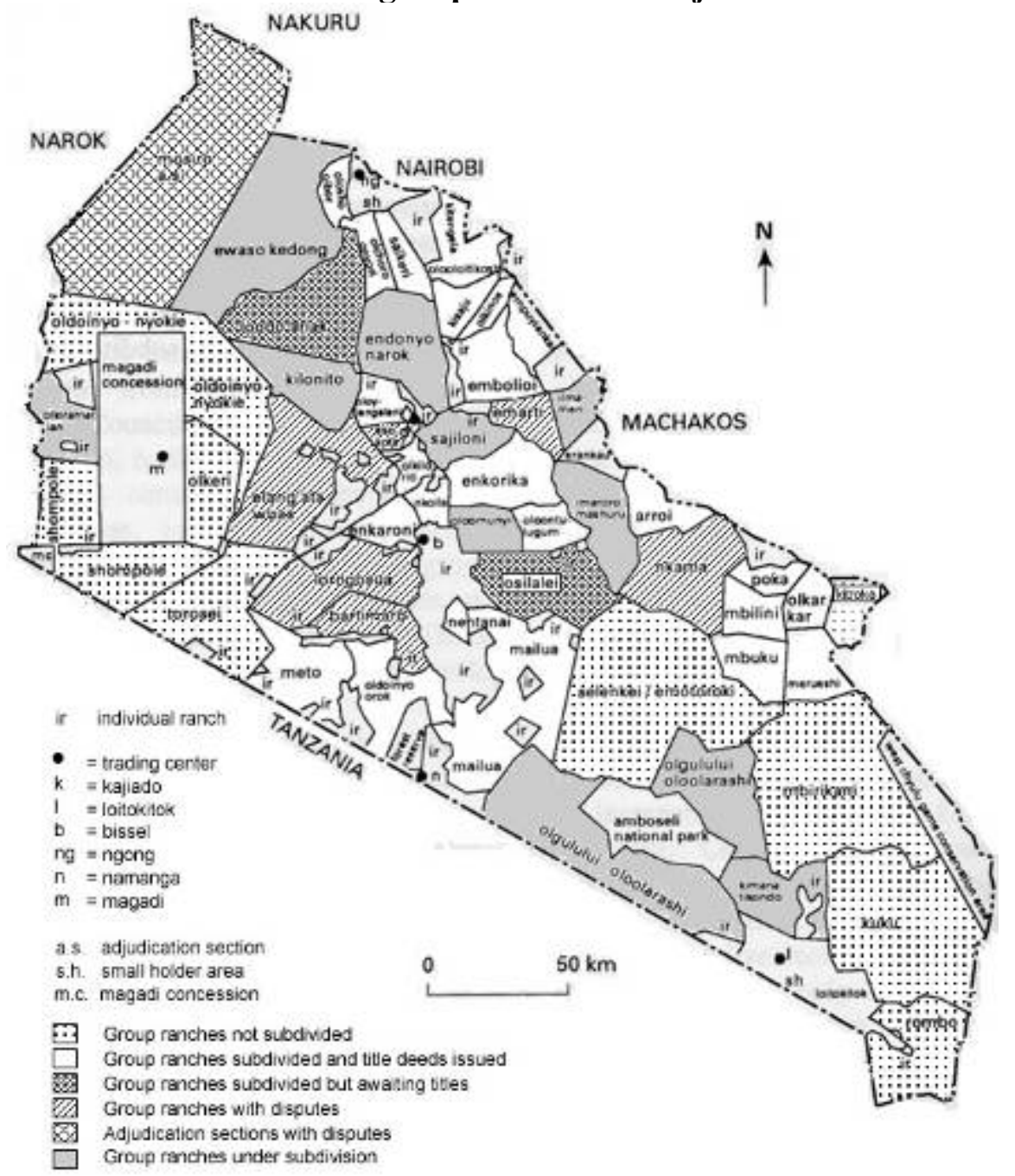

Source: Land Adjudication Department, 2002

Only five have not started to subdivide; these include: Olkeri, Shompole, Ooldonyonyokie, Kuku, and Torosei. While official record of the total number of group ranches in the district seems to vary between the two time periods (i.e. 56 in 2002-see Mwangi, 2003; and 52 in 2006), it is worth noting that five other group ranches which had not resolved to subdivide in 2002 are now in the process, and one has completed. These include Olosho-Oiborr, Eselenkei, Emotoroki, Imbirikani, and Rombo. Thus, there are only limited areas where the transition from communally managed lands has not yet begun or occurred. Interestingly, areas that are not yet divided are 
those in the driest regions of the district, suggesting that pastoralists themselves recognize the difficulties of subdivision in dry environments.

The trend towards subdivision implies dramatic changes in pastoral land use - from a system predicated on extensive seasonal movement and intensive, short-duration grazing of successive areas of the pastoral landscape, towards one based on intensive, long-term grazing of private parcels where households have ostensibly fewer options for mobility. Pastoral households are also questioning whether individual parcels are economically viable. Similarly, greater articulation between Maasai pastoralists and the larger Kenyan economy, and changing livelihood risks and expectations of pastoralists themselves have led researchers to predict a shift on the part of pastoralists towards strategies that augment livestock production activities (Zaal 1999, Little et al. 2001).

Preliminary research in Maasai group ranches at different stages in the process of land subdivision offers convincing evidence that even while herders are attempting to diversify and intensify their production strategies (Little 2001, Mwangi 2003; BurnSilver 2006; Mwangi, 2006b), they are also taking steps to re-aggregate their spatial access to resources through pasture sharing and swapping mechanisms. These emergent strategies are interesting because they represent examples of sustained collective action after the dissolution of group ranches - either a strengthening of traditional norms or the creation of new ones - whereas the obvious prediction would be their decline (Ostrom pers. comm., Mwangi 2003, BurnSilver 2006; Mwangi, 2006b).

This paper explores the policy problems raised by the specter of fragmenting a collectively owned and appropriated resource system that is characterized by variability at spatial and temporal scales. It examines emerging (as well as prior) collective arrangements and mechanisms for re-aggregating subdivided parcels, and asks why herders are adopting these 
strategies in a post subdivision setting. Collective outcomes are theoretically unexpected under a subdivided property assignment. The high transactions costs of negotiating access amongst a large number of individual parcel owners may likely offset aggregation benefits, even where individuals commit not to pursue hold out strategies. Furthermore, because individualization is supposed to ensure that individuals reap the returns to their investment, there is little incentive for group effort. Thus, collective action observed in the post-subdivision setting requires explanation, and policy implications should be clarified. Below we outline a series of questions used to explore and describe these re-aggregation mechanisms:

- What kinds of re-aggregation mechanisms and examples of collective action are emerging in a post-subdivision environment? Why?

- What factors influence the different mechanisms? Is there a pattern to re-aggregation across the group ranches?

- How do these arrangements work?

We expect that:

- These emerging collective action mechanisms, including both re-aggregation and social networking strategies, will be built on pre-existing cultural norms (e.g. herd redistribution, stock-sharing relationships, and maintenance of shared infrastructure) in order for herders to renegotiate access to grazing areas and critical resources.

- Additional re-aggregation strategies will emerge based on new economic norms that are negotiated between pastoral households (e.g. pasture leasing).

- The decision of pastoral households to take part in collective action strategies will depend on the size of household herds and the size of subdivided parcels.

We argue that these re-aggregation mechanisms and collective action more generally are crucial ways for maintaining the flexibility that is necessary for livestock production in variable environments, rendered even more risky after subdivision. However, official policy at different 
governance levels has not kept pace with these ongoing developments. Subdivision now is largely considered "inevitable" by both policy makers and pastoralists - even as substantial uncertainties and misgivings with the implications of the process remain in the minds of many. Importantly, policy narratives in response to the question of "what comes after subdivision" are mixed, ranging from expectations of widespread ecological degradation, to the emergence of a modern ranching sector, to increasing poverty and an end of traditional pastoralism. However, the emergent re-aggregation strategies speak of a series of different potential outcomes and new opportunities for flexibility, mobility, and sustainability for pastoral livelihoods that we examine in this paper.

\section{The Policy Context for Subdivision}

The policy context for the subdivision of Maasai group ranches is well known. The Maasai group ranches were created in 1968, authorized by the Group (Land Representatives) Act. Concerned with range degradation, government officials thought that group ranches would create incentives for Maasai to reduce their large herds, the perceived cause of degradation. Maasai herds would be confined within a bounded space under the watch of a group ranch management committee that would also enforce livestock quotas to control stocking levels. Excess livestock would be culled for the market, and group title would be used as collateral for development of livestock infrastructure. The management committee (elected via majority voting) would oversee pasture management and water development in the group ranch. This policy drew heavily from the tragedy-of-the-commons thesis (Hardin 1968) and was implemented as two phases of the Livestock Development Program in Maasailand by various departments of the Kenya Government with support from the World Bank and several bilateral donors. 
Communally used Maasai rangeland was thus adjudicated, and corporate titles were issued to groups of Maasai. However, 15 years later many group ranches began to subdivide and distribute individual, titled parcels to shareholding members. The motivations, rates, and outcomes of group ranch subdivision have been widely documented (Mwangi, 2006a, 2005; Galaty, 1999, 1994a,b, 1993, 1992,; Ole Simel,1999; Kimani and Pickard, 1998; Rutten, 1992; Kituyi, 1990; Kipury, 1989; Doherty, 1987; Grandin, 1987; Munei, 1987). While many reasons have been cited for subdivision, an overriding concern was poor management and lack of accountability (of both the group's committee and in supporting organizations), which severely undermined the incentives for individuals to remain in the group. Increasing group ranch populations, discord between age-sets concerning registration of new members, unsanctioned allocations to unauthorized individuals, difficulties in enforcing livestock quotas, inability to repay loans issued to group ranches, misappropriation of loans issued to group ranches, and an ambivalent (and often predatory) bureaucracy were the problems that created insecurity among group members and pushed them to support subdivision. Subdivision outcomes were remarkably similar in many of the subdivided group ranches: poorer herders were allocated smaller sized parcels, women and youths were locked out of decision making and land given to household heads, primarily men and some widows. Judicial and bureaucratic processes did not offer redress, and losers failed to turn around undesired outcomes.

Property rights theories predict that rights evolve towards greater specificity and efficiency (Demsetz, 1967). Because an individual owner obtains both costs and benefits of his actions on a resource, he will have greater incentives to invest in its management. Individual rights would also stimulate market exchange and provide opportunities for transferring the resource to a higher value user who will subsequently invest more in the resource. The 
implication of this process is increased atomization; each individual will adopt strategies to maximize benefits from their individually owned resources. It also implies that private, individual rights are an endpoint in themselves. However, the theory overlooks the possibility that rights are constituted in bundles and that, even where one individual owner has full ownership rights, they may confer use and/or management rights to other individuals under specified agreements and arrangements (Meinzen-Dick et al, 1997; Ostrom and Schlager, 1996; Schlager and Ostrom, 1992). In addition to this, there is also scope for individual owners to jointly invest in mutually beneficial collective enterprises. A large body of collective action literature provides some indication of the conditions under which collective action is likely (Ostrom, 2005, Ostrom, 1990; Ostrom et al, 2002, Baland and Platteau, 1996).

Collective action in a post subdivision situation is generally theoretically unexpected. Moreover, as suggested by Mwangi (2006a), we reiterate that property rights evolution does not necessarily end when individual titles are issued to Maasai herders. Instead, there is continued recontracting as individuals and groups seek arrangements they anticipate will enhance viability and improve outcomes in a risky environmental setting. We do not advocate for rangeland subdivision, but we illustrate a range of behavioral options that Maasai are using to improve flexibility in a subdivided situation. We suggest that these behaviors are instructive to policy both locally and globally.

\section{Study areas}

The work of BurnSilver (2006) looked at land use and land tenure change and its effects on economic strategies in southern Kajiado district. Four group ranches were the focus of this work; one recently divided ranch (Osilalei - 53,600 ha) and three Amboseli area group ranches that are as yet largely unsubdivided (Imbirikani - 122,893 ha / 4,585 members, 
Olgulului/Lolarrashi - 147,050 ha / 3,418 members, and Eselenkei - 74,794 ha / 1,200 members) (Ntiati 2002). Osilalei Group Ranch members voted to subdivide in 1990, and since this time most extended households gradually split in order for parcel holders to take up residence on their individual parcels. Households currently are using brush fencing to mark boundaries between parcels, and herds move between private land and water points using communal throughfares. Highland rainfed agricultural areas in Olgulului/Lolarashi (e.g. Emurutot) and irrigated agricultural areas on Imbirikani and Olgulului/Lolarashi (e.g. Namelok and Kimana swamps) have been, or are in the process of being subdivided on a formal basis. Group ranch members are now debating whether subdivision of core rangelands should occur and if so, then how (Ntiati 2002).

Mwangi (2003) examined why Maasai in the central Kajiado District group ranches of Enkaroni, Meto, and Nentanai supported group ranch subdivision, how group land was allocated amongst registered members, and the distributional outcomes of subdivision. These three group ranches decided to subdivide between 1987 and 1989. Meto, the largest group ranch, covers an area of 28,928 ha, with 645 members. Enkaroni is the second largest with 310 members and a size of 11,378 . Nentanai is the smallest group ranch, with 57 members and is 3,696 ha. The physical environment across the seven group ranches is characterized as arid or semi-arid lands, zones (V and VI) (Kenya, Republic of, 1990; Ole Katampoi et al. 1990).

At the core of the Amboseli study area is Amboseli National Park (Figure 2). 
Figure 2: Southern Kajiado Study Area

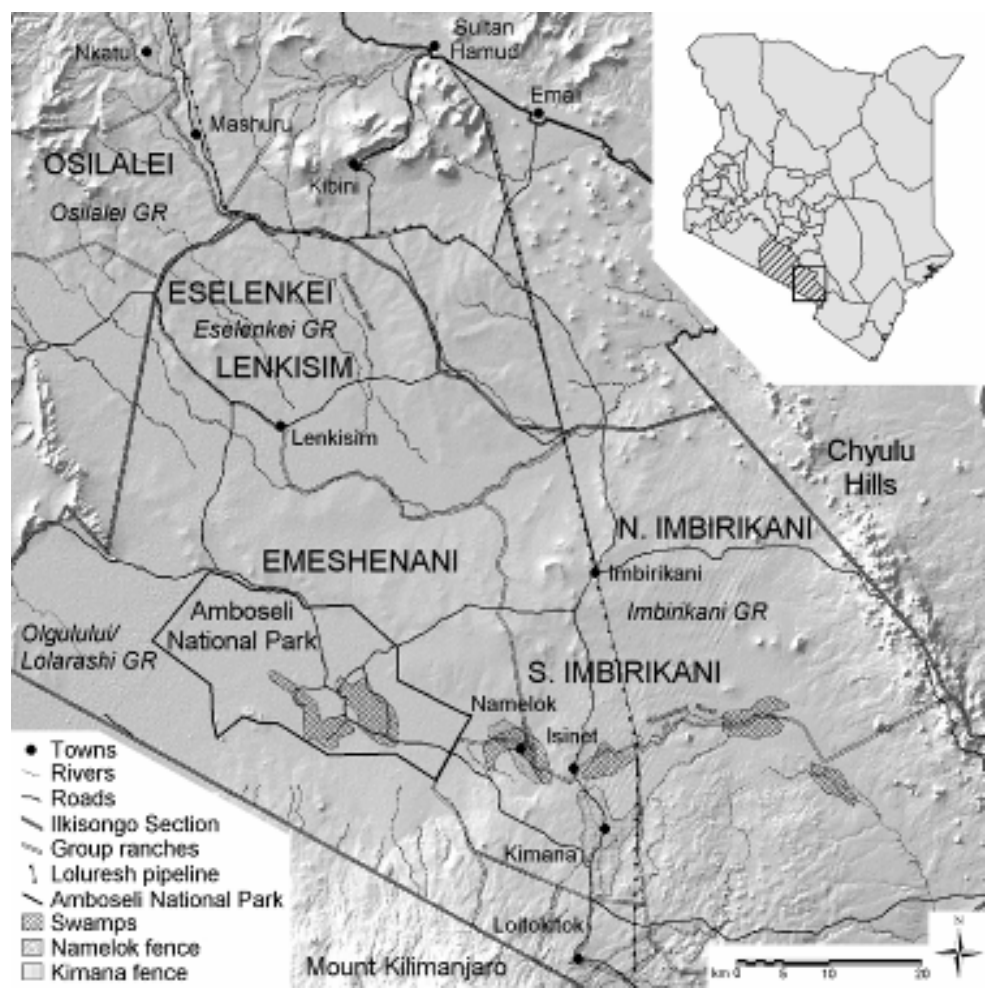

Figure 3--Central Kajiado Study Area

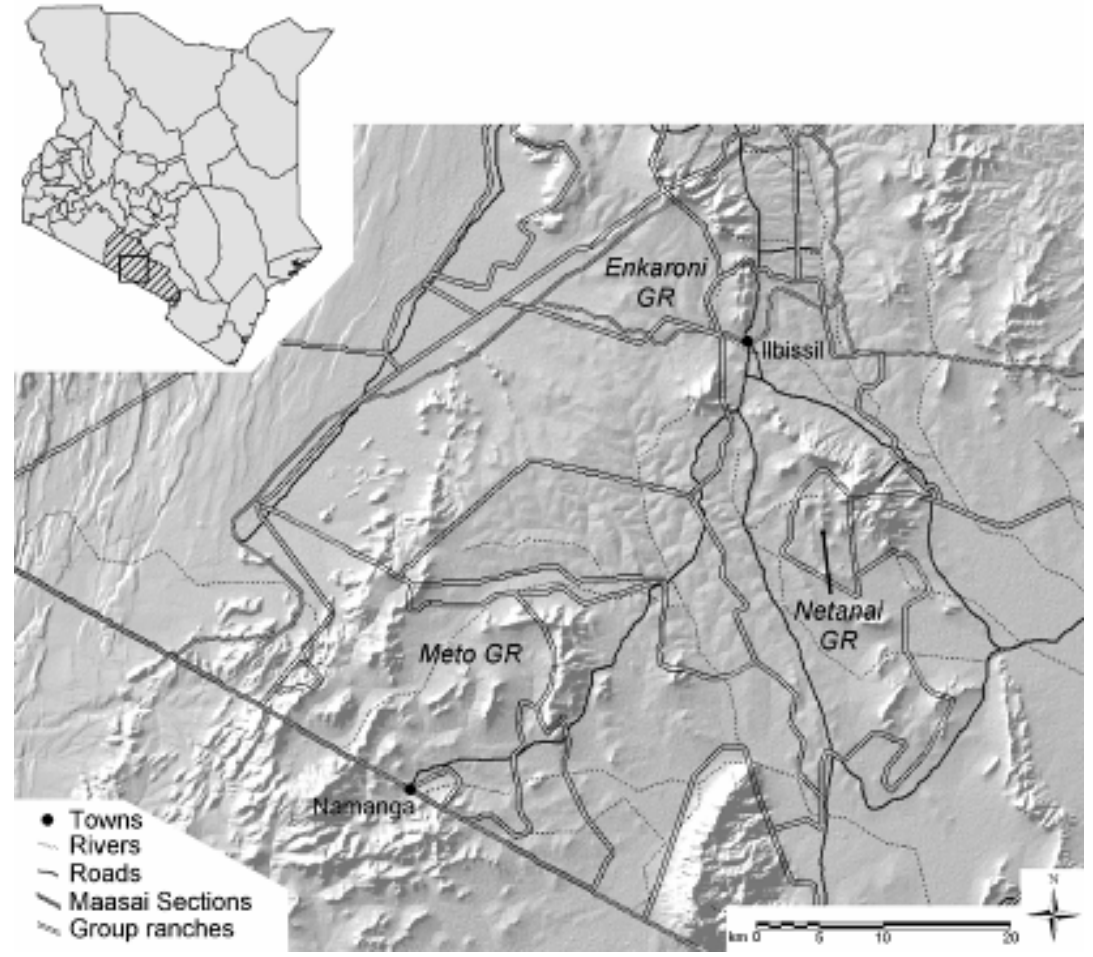

Source: Lines in figures 2 and 3 are from the Kajiado District Atlas (Ole Katampoi 1990) overlaid on topography from the Shuttle Radar Topography Mission, 2000. 
The area is bounded by higher altitude zones to the east (e.g. the Chyulu Hills) and to the south by Mt. Kilimanjaro. Altitude gradually rises to the north moving towards the Pelewa hills and Athi-Kapiti plains. A decreasing rainfall gradient extends north-south from Osilalei (500$600 \mathrm{~mm} / \mathrm{yr})$ to the Amboseli basin $(350 \mathrm{~mm} / \mathrm{yr})$. Enkaroni, Meto, and Nentanai are in the Central Ecological Zone with annual average rainfalls of about $500 \mathrm{~mm}$ where the conditions of soils, geology, and topography are relatively unvarying (ETC East Africa, 1998).

Rainfall patterns in Kajiado district are bimodal, but rainfall is highly variable in both space and time. Combined with underlying topographic and edaphic gradients, the result is a mosaic of vegetation types that include grasslands, wooded grasslands, and bushlands. These fundamental ecological characteristics of the system translate into a productive landscape for pastoralists in which forage quality and quantity are extremely patchy and unpredictable - the traditional response to which has been pastoral transhumance and flexible but negotiated access to communal rangeland territories.

Low access to significant infrastructure for pastoral households is an additional characteristic of the seven Maasai group ranches focused on in this paper. Livestock markets are distant from most household locations, information regarding livestock prices is incomplete, and prices are not stable (Rutten 1992, Zaal 1999). Government-supported veterinary services have declined in Kenya (and Sub-Saharan Africa in general) as a result of structural adjustment programs (Leonard 2003), and most households now administer veterinary drugs purchased privately. Livestock disease remains a strong limitation to household livelihoods in pastoral areas (FAO 2002). Schools, health services and other basic services (e.g. food markets) usually are located only along major roads. For Enkaroni, Meto, and Nentanai, these services lie along the Namanga highway, and for the Amboseli group ranches they are arranged along the 
unimproved Emali-Loitokitok road. This leaves households in large core areas of both study areas with low to minimal access to a range of basic services.

A combination of land tenure change, livelihood choices and differential access to infrastructure has contributed to general patterns of land use across the study areas. Sedentary agropastoralism is the dominant land use around the Amboseli swamps, while more extensive pastoralism characterizes Lenkisim, Eselenkei, Emeshenani, and N. Imbirikani. Households in subdivided Osilalei, Enkaroni, Meto, and Nentania are also more sedentary and engage in some rainfed agricultural activities.

\section{Data and Methodology}

This paper leverages data and results from two $\mathrm{PhD}$ studies carried out across eight Kajiado group ranches. These data sets offer a unique opportunity to look at emergent pre- and post-subdivision trends from an interdisciplinary framework that combines ecological, political, and human-ecological research perspectives.

BurnSilver carried out field research in Amboseli November 1999 to March 2001. Fieldwork occurred in six study areas across the four group ranches: Osilalei, Eselenkei, Lenkisim, Emeshenani, South Imbirikani and North Imbirikani (Figure 2). A sample of 184 pastoral households was chosen based on a proportional random sampling technique stratified on the basis of location $(\mathrm{n}=6)$ and wealth (e.g. richer, poorer and middle-income households). Households were interviewed in order to gather data on socio-demographic characteristics, economic strategies (e.g. livestock, agriculture and off-farm activities), animal numbers, livestock management, and verbal descriptions of monthly movement patterns for 24 months across a good year, with average annual rainfall (1999) and a bad year, with drought (2000). These descriptions of grazing movements are geo-referenced and form the core of a mobility 
data set for subdivided Osilalei and unsubdivided Olgulului/Lolarashi, Imbirikani, and Eselenkei Group Ranches.

Household wealth was identified using Grandin's (1988) wealth ranking technique and yielded the following distribution: Poor 34.7 percent, Medium 37.3 percent and Rich 28.3 percent. Mean tropical livestock units (for both cattle and smallstock) held by rich, medium, and poor sampled households were 126.4, 47.0 and 23.5 TLUs, respectively. Livestock revenue and in-kind consumption combined represent an average of 64 percent of gross household income for the combined study sample, but relative dependence on livestock activities ranges from 45-84 percent depending on location (e.g. highest in dry, isolated Emeshenani and lowest in agropastoral S. Imbirikani). However, 51 percent $(\mathrm{N}=93)$ of households combined livestock activities with either rainfed or irrigated agricultural activities, and 59 percent $(\mathrm{N}=108)$ of households were engaged in at least one off-farm activity - either wage labor, business, or petty trade. Fourteen percent of households engaged in two off-farm activities, and 8 percent were very diversified, gaining income from between three and six off-farm activities. Return trips by BurnSilver to the Amboseli study area in 2003, 2004, and 2005 for dissemination of research results, and a series of focus groups on subdivision issues in collaboration with ILRIs Ereto-oEreto project provide considerable context for subdivision issues discussed in the context of this paper.

Mwangi’s fieldwork took place from January to December 2001, with follow up activities from June to September of 2002. The data presented in this paper are a subset of 154 interviews drawn from a wider set of 334 interviews with elders, youths, married women, and widows from the three study sites where subdivision has occurred. The data is used to provide insights into the following issues: the nature of collective activities that individuals pursue after 
subdivision and the emergence of pasture sharing arrangements. Results are disaggregated by wealth/livestock numbers, parcel size, age-set, and gender and are analyzed via descriptive statistics and chi-square analysis.

The subset of 154 represents individuals, i.e. men of varying ages and widows, who were registered as group ranch members and who subsequently received individual parcels after group ranch subdivision. Out of these, 24 were widows and 130 were males of various age sets. Most of them (110) had no formal education; seven had attended adult literacy classes, 15 upper primary, eight lower primary, four secondary school, one high school, and seven attended college. Livestock continues to be the main income source for a majority of the respondents. Of 154 individuals, 130 indicated a reliance on livestock as a first/main source of income, seven on subsistence farming, six on wage/labor employment, and one on remittances. A total of 112 individuals indicated that they have a second source of income. Out of these, 88 were involved in subsistence farming, nine in wage labor/employment, seven depended on remittances from relatives, and three depended on charcoal making. A total of 45 individuals registered a third source of income. 20 out of these indicated they were involved in wage labor and employment, while 12 were involved in different forms of retail businesses.

As a result of subdivision of the three group ranches, 21 individuals have parcels 25 ha or less, 63 received parcels ranging in size between $26-50$ ha, 31 have parcels ranging in size between 51-75 ha, 8 have parcels of 101-125 ha, four have parcels of 126-150 ha, and six have more than 150 ha. Average sizes of parcels per group ranch are shown in Table 1, but these figures disguise some variability.

Table 1. Actual and potential sizes of individual parcels under subdivision

\begin{tabular}{lll}
\hline \hline Group Ranch & $\begin{array}{l}\text { Average parcel } \\
\text { size (ha) }\end{array}$ & $\begin{array}{l}\text { Comparison of } 1 \mathrm{~km}^{2} \\
\text { resolution in analyses } \\
\text { to subdivided parcel sizes }\end{array}$ \\
\hline Imbirikani* & 26.8 & 9 times larger $\left(0.11 \mathrm{~km}^{2}\right)$
\end{tabular}




\begin{tabular}{lccc} 
Olgulului/Lolarashi* & 43.0 & 5.8 & $\left(0.17 \mathrm{~km}^{2}\right)$ \\
Osilalei & $40.5+/-$ & 6.3 & $\left(0.16 \mathrm{~km}^{2}\right)$ \\
Eselenkei* & 60.0 & 4.2 & $\left(0.24 \mathrm{~km}^{2}\right)$ \\
Meto + & $35.56(.379)$ & 7.1 & $\left(0.14 \mathrm{~km}^{2}\right)$ \\
Enkaroni + & $49.92(.233)$ & 5.0 & $\left(0.20 \mathrm{~km}^{2}\right)$ \\
Nentanai + & $72.12(.399)$ & 3.5 & $\left(0.29 \mathrm{~km}^{2}\right)$ \\
\hline
\end{tabular}

+ Average parcel size after subdivision, with gini coefficients in parentheses demonstrating the skewed distribution of parcel sizes (Mwangi 2006, 2003) *Potential size of parcel given size of ranch/no. of members in 2001 (Ntiati 2002)

In order to illustrate conceptually the loss of flexibility represented by subdivision, we averaged trends in normalized difference vegetation indices (NDVI) for 10-day composite periods from April 1998 to March 2004 (Vito 2002). NDVI measurements reported here were taken from $1 \mathrm{~km}^{2}$ resolution SPOT Vegetation NDVI data. We plotted averaged NDVI values over an annual 12-month period for each $1 \mathrm{~km}^{2}$ patch within the group ranches. This process yielded NDVI profiles which represent the forage hypothetically available to households in any $1 \mathrm{~km}^{2}$ location. Profiles were manipulated to represent subdivision scenarios that mimic available forage at three different scales of household mobility and cooperation: 1) presubdivision group ranches, 2) five $1 \mathrm{~km}^{2}$ adjacent individual parcels within each group ranch, and 3) five $1 \mathrm{~km}^{2}$ non-contiguous parcels within each ranch. It is worth mentioning here that the $1 \mathrm{~km}^{2}$ base resolution of the NDVI data is a size many times that of individual parcels either received or potentially given out in the seven group ranches studied here (Table 1). The location of the contiguous and random parcels for these analyses was made randomly, and the choice to compare NDVI values across $5 \mathrm{~km}^{2}$ reflects our hypothesis that the contiguous area would include a group of herders small enough to know each other well and therefore collaborate on pasture swapping, but large enough to include critical ecological diversity in forage responses. We present additional results based on a series of focus groups. In January of 2005, BurnSilver conducted 14 focus groups with a total of 75 people in Kimana, Eselenkei, 
Olgulului/Lolarashi, and Imbirirkani Group Ranches. Focus group respondents were junior and senior elders in equal proportion, from both wealthy and poor households. One meeting was with women, and 7 others included either group ranch committee members and/or area chiefs. These meetings were carried out under the auspices of ILRI's Ereto-O-Ereto Project and consequently included Kimana group ranch, but not Osilalei, which was outside the project focal area. Focus group participants were asked to comment on the major issues facing "people, livestock and the environment" in their areas.

\section{RESULTS}

\section{NDVI analyses}

The results of the NDVI analyses conceptually illustrate the effects of subdivision, and potential sharing mechanisms on pastoralists' ability to access forage greenness. Taking vertical slices through the NDVI profiles in figures $4 \mathrm{a}$ and $4 \mathrm{~b}$ during any time of the year illustrates the diversity of forage responses available to herders first in pre-subdivision, intact group ranches, and then in each group ranch post-subdivision if sharing occurs between households. 
Figure 4a: NDVI Profiles for Imbirikani, Olgulului/Lolarashi, Eselenkei and Osilalei Group Ranches

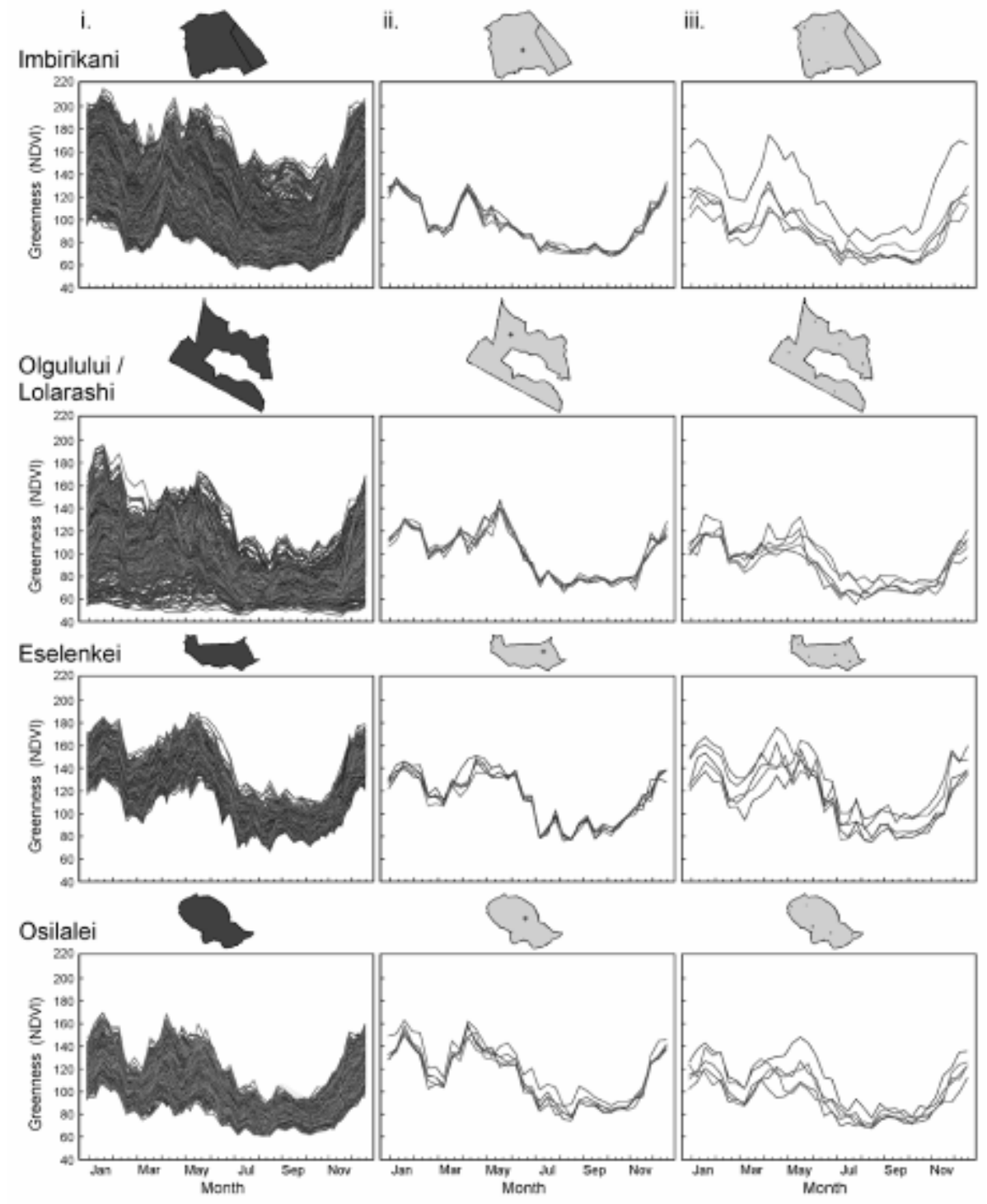




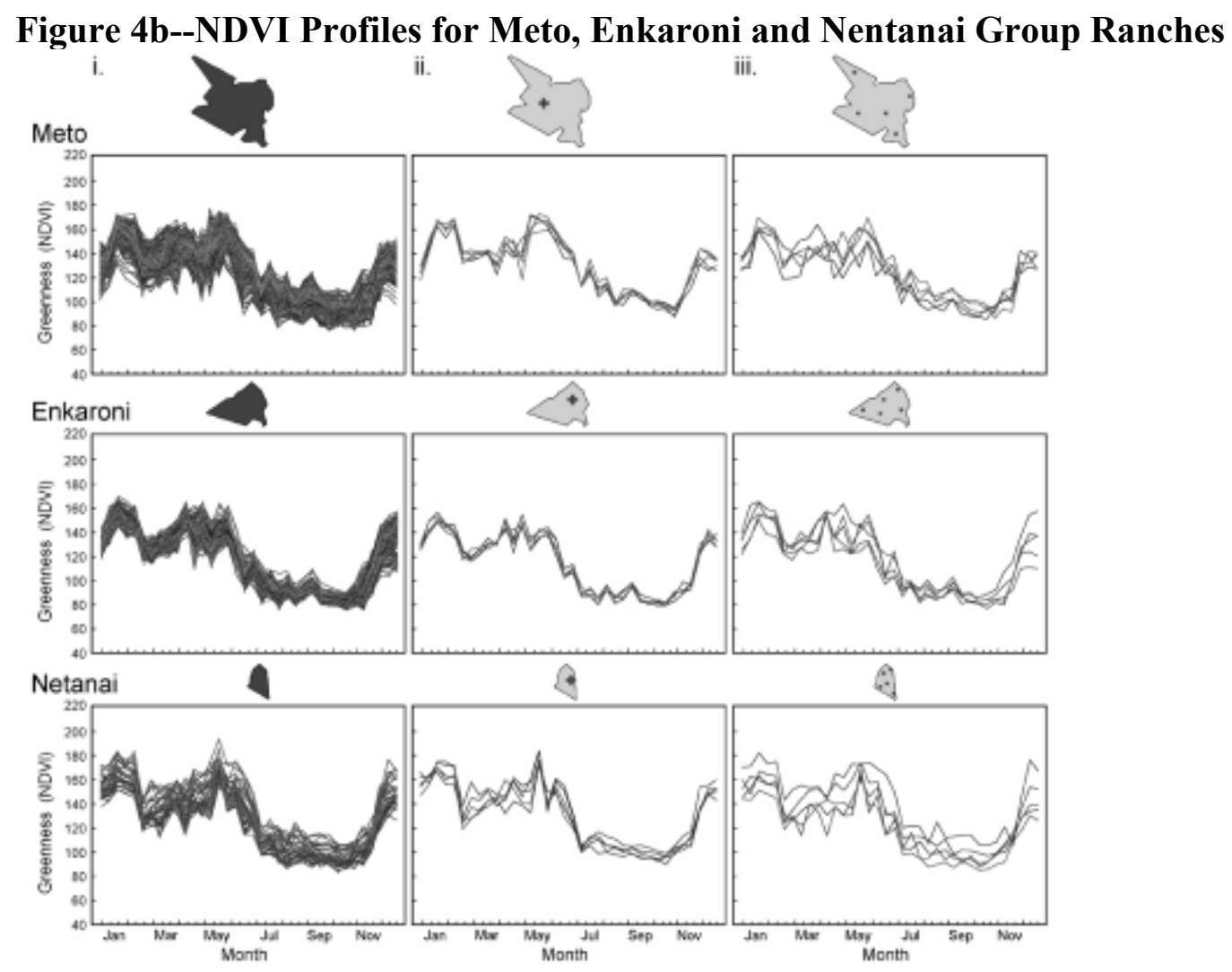

The sharing scenarios illustrated here come directly from discussions with Amboseli area pastoral households, and reflect the opinions of herders that some sort of pasture sharing mechanisms would be critical in a post-subdivision environment. They are also useful in conceptualizing why households in Nentanai, Meto, and Enkaroni might use sharing mechanisms in these subdivided group ranches.

The rise and fall patterns of NDVI values across a calendar year are similar across all the ranches and reflect the bimodal distribution of rainfall in these areas, e.g. relatively high values during two rainy seasons (Mar-May and late Oct-Dec), alternating with two dry seasons, one short (Jan-Feb), and one long (June-Oct). However, not all ranches are the same in terms of forage productivity (e.g. greenness). Note that both the range of NDVI values (e.g. the range of low and high values on the $y$-axis) and the depth of the combined profiles for each group ranch 
are different. A higher range of values implies greater forage greenness and is linked to higher average rainfall and underlying topography. The absolute number of NDVI profiles in Column $i$ (Figures $4 \mathrm{a}$ and $4 \mathrm{~b}$ ) pictured for each group ranch reflects the size of the ranch area, so large ranches have many profiles and small ranches relatively fewer, but the depth of the combined band of NDVI profiles indicates the range of grazing choices available to herders in a presubdivision environment - when they could migrate within each ranch based purely on forage quality and/or quantity preferences. The depth of the NDVI profiles therefore corresponds to greater ecological heterogeneity within any group ranch (Boone and Hobbs 2004). So, for example, Imbirikani and Olgulului/Lolarashi ranches are both large and contain within their boundaries a wide diversity NDVI greenness profiles, indicating that some areas are very green all the time and some are not. In contrast, Meto ranch is also large, but the profile depth is much smaller (e.g. less heterogeneity). Additionally, Meto profiles have relatively high greenness values overall. One might argue therefore that the importance of mobility in Olgulului/Lolarashi and Imbirikani ranches is even greater than for Meto, and, in fact, the impact of subdivision is potentially greater in drier areas. Yet, it is clear conceptually that mobility is important in all seven of the group ranches pictured here - whether in areas of lower or higher average productivity - given that in any one month of a year some areas on each ranch are greener than others.

Column $i$ in Figures $4 \mathrm{a}$ and $4 \mathrm{~b}$ depicts that forage options for individual herders decrease dramatically under privatization, but rebound somewhat when parcels are shared between households located adjacent to each other. Each individual line represents the limited forage options available within a hypothetical $1 \mathrm{~km}^{2}$ parcel, an area that we have illustrated is already significantly larger than that actually or potentially received by any one pastoral household 
(Table 1). However, the depth of the NDVI profiles widens, reflecting increases in access to forage if households share their parcels with other contiguous households within a $5 \mathrm{~km}^{2}$ area.

Carrying the concept of parcel sharing even further, we see that grazing options expand once again through sharing of $1 \mathrm{~km}^{2}$ pastures that are distributed randomly (Column iii). This latter result reflects the underlying ecological heterogeneity of the landscape in Kajiado, so that parcels further away from each other have a greater probability of either receiving different levels of rainfall, or representing a different vegetation community type - both of which imply expanded forage options available for herders. The underlying ecological heterogeneity on the seven group ranches is reflected in the depth of the NDVI profiles in Column iii. For example, Imbirikani seems to be more diverse than the other ranches. This makes sense, because the analyses included a parcel in the higher altitude of Chyulu Hills - an area long considered to be a drought refuge by pastoralists.

\section{Emergent re-aggregation mechanisms}

A range of post-subdivision mechanisms have emerged in Nentanai, Meto, and Enkaroni group ranches that act to re-aggregate household access to forage outside of private parcels. Households redistribute portions of their herds for long periods and swap/share pastures. Movement of animals occurs between parcels (e.g. shambas) owned by members of extended families (sons, fathers, in-laws) and between the shambas of friends (age-mates, clan-mates, and stock associates). Giving out animals, sharing or swapping of pastures occurs with the understanding that movement between parcels is based on need and reciprocal in time and reflects efforts at rotational grazing between their shared space. Some leasing arrangements also occur based on monetary exchange or payment for pasture with animals, but these purely economic arrangements are reportedly more rarely. 
Thirty-nine percent ( $\mathrm{n}=53$ of 136, 18 non responses) of the individuals from Enkaroni, Meto, and Nentanai indicated that some of their livestock were resident on a full-time basis away from their parcels at the time of the survey. Out of the 53 individuals with livestock not resident on their parcels, most of these animals (57 percent) were distributed with family (i.e. with brother, sister, second wife, in-laws) and members in the same group ranch. Twenty-two percent had distributed to friends in the same group ranch, while 18 percent indicated that their livestock were distributed across multiple shambas that they owned. A small proportion, about 4 percent, indicated some of their livestock were resident in other locations (Elangata Wuas Group Ranch and in Tanzania). Pasture leasing was also used in order to redistribute animals. Eleven individuals (on Enkaroni and Meto) indicated that they are leasing out and/or buying pasture access at a fee that ranges between KShs 500-1500 per month (US \$7.14-21.43). Out of these 11 households, three were straight up leases and eight were a mix of leasing and pasture sharing, or leasing additional pastures with no sharing arrangements. Table 2 provides a breakdown of these emerging arrangements.

\section{Table 2--Type of grazing arrangements in Enkaroni, Nentanai and Meto group ranches}

\begin{tabular}{lcccc} 
Grazing Arrangements & Frequency* & Percent & Valid Percent & Cumulative Percent \\
\hline Yes & 59 & 38.3 & 41.8 & 41.8 \\
Yes + Lease & 2 & 1.3 & 1.4 & 43.3 \\
None & 71 & 46.1 & 50.4 & 93.6 \\
No + Lease & 6 & 3.9 & 4.3 & 97.9 \\
Lease Only & 3 & 1.9 & 2.1 & 100.0 \\
Total & 141 & 91.6 & 100.0 & \\
Missing & 13 & 8.4 & & \\
Total & 154 & 100.0 & & \\
\hline
\end{tabular}

*Total $\mathrm{N}=154$

Those with larger herds were more likely to have redistributed some or all of their animals (for combined sheep, goats and cows: chi sq. $=18.67, \mathrm{p}<0.001$; for cattle only, chi 
$\mathrm{sq} .=29.03, \mathrm{p}<0.0001)$. However, neither parcel size (chi sq. $=10.243, \mathrm{p}=0.069)$ nor group ranch membership ( $\mathrm{chi}=.402 ; \mathrm{p}=0.818)$ seems to influence the decision to re-distribute herds.

The distribution of livestock among friends and family located in the same group ranch reflects other underlying arrangements among these actors (Mwangi, 2003, 2006a). One individual in Meto stated that he accommodates a friend's animals on his parcel because this allows him free use of the friend's borehole to water his animals. Sixty-one percent of respondents ( $\mathrm{n}=136,18$ non responses) did not have livestock resident on other parcels at the time they were surveyed. Additionally, when individuals did not have standing arrangements for shared grazing $(\mathrm{n}=71)$, most suggested that livestock numbers (and land) are unequally held and that when such arrangements are made richer herders tend to benefit more. In addition, they felt their pastures are already inadequate for their own needs.

\section{Grazing movements}

Once subdivision has occurred, a common assumption of policy makers is that households will stay on their individual parcels on a year-round basis. This will lead herders to intensify their livestock production strategies, e.g. eventually adjusting their livestock numbers downward through increased engagement with the marketplace (Rutten 1992). However, results from four subdivided ranches belie the initial assumption of continuous grazing on individual parcels.

When herders on Meto, Enkaroni, and Nentanai were asked whether they moved their livestock out of their individual parcels during the course of the year, 71 percent $(n=134$ of 154 respondents, with 20 missing values) replied in the affirmative. Most herders (i.e. 48 percent $\mathrm{n}=103)$ moved them to neighboring parcels, 19 percent $(n=103)$ to neighboring group ranches, 30 percent $(n=103)$ to other places (e.g. other group ranches and Tanzania). Most (93 percent; $n=97$ 
out of 154) respondents moved their livestock during the dry season and during drought (chi $\mathrm{sq} .=12.408 ; \mathrm{p}=0.006$ ). Six households stated they moved because their pastures were inadequate. Those with larger cattle herds were more likely to move (chi sq. $=19.272 ; \mathrm{p}=0.002$ ). Once again, parcel size does not seem to matter, as individuals with large, medium, or small parcels are mobile (chi sq. $=3.498 ; \mathrm{p}=0.744)$.

Results from subdivided Osilalei also indicate that households continue to be mobile when necessary. Although only two surveyed Osilalei households moved off their private parcels in 1999 - the year of normal rainfall, 75 percent $(n=21)$ of surveyed households migrated in the drought year of 2000, and 10 of these households migrated long-distances outside of the group ranch boundaries. These herders negotiated access to Ilkisongo Maasai Section and migrated to Imbirikani Group Ranch along the base of the Chyulu hills, one of the few areas in the district that still had forage by August of 2000 at the height of the drought. The 11 remaining mobile Osilalei households moved within ranch boundaries, reportedly based on kin and stocksharing relationships.

BurnSilver found that while mobility continues to be the norm for most areas in southern Kajiado, mobility patterns differed by location and annual rainfall conditions (Figure 5). 


\section{Figure 5--Comparison of Household Mobility across Amboseli Study Areas}

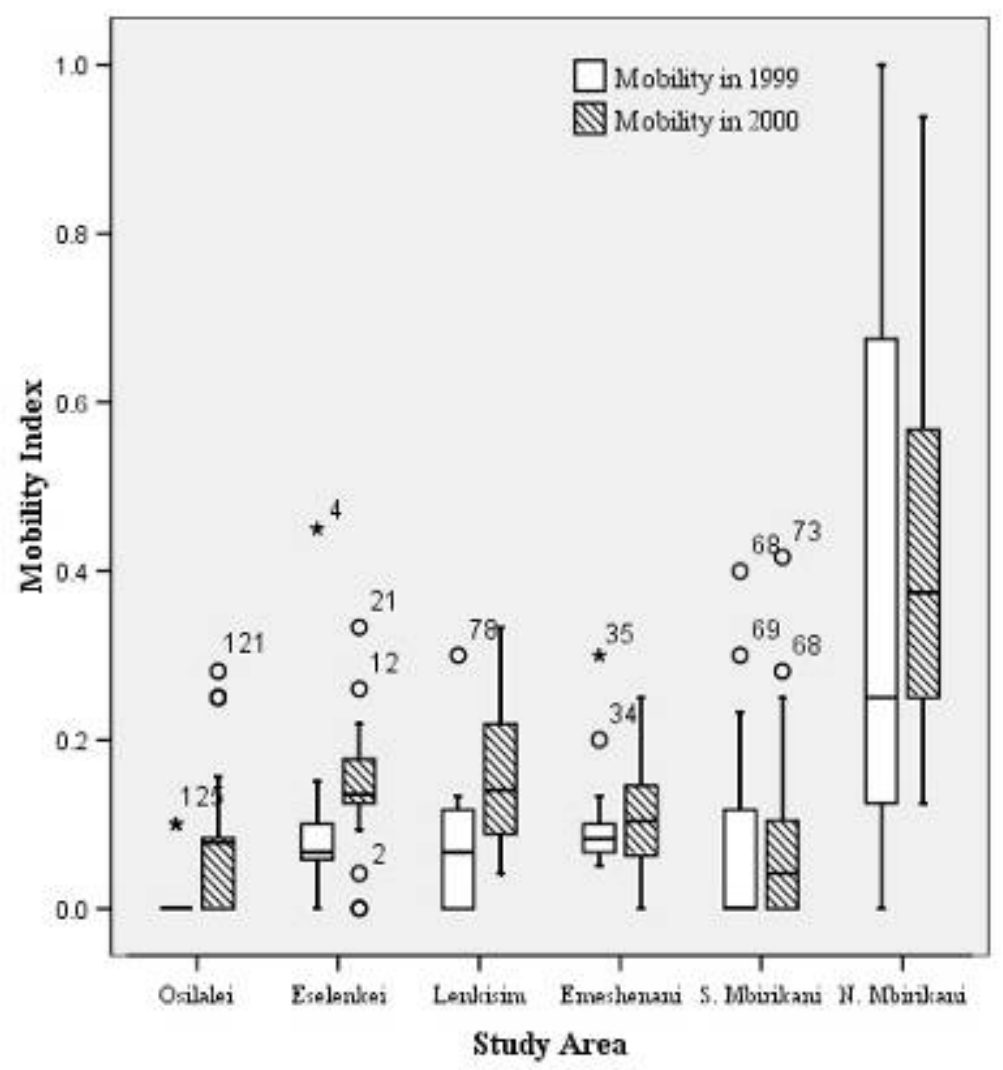

Mobility was calculated here as an index based on a combination of: 1) number of moves per year of the main cattle herd away from a household's permanent settlement, and 2) total number of months the main herd remained away from the permanent settlement. Households across all sites were more mobile on average in the drought year of 2000 than they were in the normal rainfall year of 1999 - the exception was N. Imbirikani where households were highly mobile in both years, but the variability in degree of mobility declined in 2000. Sixty-one percent of households moved at least once in 1999 , while this figure rose to 85 percent in 2000 . Mobility was significantly different between study areas in both years (ANOVA: $1999 \mathrm{~F}=17.828$, $\mathrm{p}<0.001 ; 2000 \mathrm{~F}=30.820, \mathrm{p}<0.001)$, Interestingly, households in subdivided Osilalei and agropastoral S. Imbirikani were clearly less mobile overall than all other study sites. This 
implies that both subdivision and agricultural activities have contributed to sedentarization of pastoral households in the Amboseli area.

What factors contributed to household mobility in southern Kajiado? Households that moved in 1999 were more apt to be mobile in $2000(\mathrm{r}=.559, \mathrm{p}<0.01)$, but neither household size (e.g. labor availability), age of the household head, or gross income correlated strongly with mobility. However, correlating size of household herds (e.g. TLUs) with mobility, we found a strong relationship for S. Imbirikani in $1999(\mathrm{r}=.682, \mathrm{p}<.01)$, and both Osilalei and S. Imbirikani in $2000(\mathrm{r}=.532, \mathrm{p}<.01$ and $\mathrm{r}=.442, \mathrm{p}<.01$ respectively). Households in the other study areas were mobile regardless of herd size. The implication is that households with larger herds have greater forage needs, and in Osilalei and S. Imbirikani, households with larger herds will be more inclined to migrate perhaps because forage availability has been circumscribed in these areas, either by small parcel size or intensive communal grazing around sedentary zones of settlement.

\section{Post-subdivision collective action}

In a post-subdivision environment, mechanisms of collective action would be predicted to decline. However, collective action mechanisms that govern access to shared resources continue to occur in Meto, Enkaroni, and Nentanai. Examples of continued cooperation include earth dams, boreholes, roads, and schools.

Individuals continue to work together to maintain the earth dams, boreholes, schools, and health clinics that were constructed when their group ranches were established. With regard to the maintenance of dams which they use to water livestock during the wet season, 61 individuals on Meto and Enkaroni ranches $(n=71$ because Nentanai does not have this facility) indicated that they ensure that the dam is well maintained through periodic dredging to remove silt, fence 
maintenance to keep out livestock, and maintenance of cattle trough and taps. Out of these individuals, 50 said that an elected committee is charged with overseeing maintenance as well as collecting money to finance maintenance activities, while an additional 11 just stated that it is their collective responsibility. Both Enkaroni and Meto have boreholes which are usually operated during the dry season. Sixty-two individuals $(\mathrm{n}=69$ because Nentanai does not have boreholes) indicated that it is a collective responsibility to maintain the water source. An elected committee is responsible for borehole maintenance, largely through paying the salary of an individual who serves as a borehole operator. Additionally, in Meto there are several private boreholes that are jointly owned by a few individuals, who have come together to provide the service. They also charge user fees and are directly responsible for the borehole's maintenance.

All three group ranches have schools. Enkaroni and Meto have primary level schools funded jointly by local government and the Kajiado county council. There is no primary school in Nentanai, but each ranch has nursery schools. The county council supplies the community with primary school teachers, but the parents are often responsible for fundraising and other maintenance activities. Parents also must organize to pay nursery school teachers. In Nentanai, an individual donated his land for the construction of the nursery school. Sixty-two out of 81 respondents (73 missing responses) indicated that primary school maintenance activities are organized by an elected committee, and an additional 16 out of the 81 indicated that school maintenance is a collective responsibility. Only two individuals indicated that they do not organize to maintain the schools, while two others suggested that the Catholic Church and the government are responsible for the schools.

Roads are critical transportation linkages in all three group ranches. Meto and Enkaroni have one all-weather (e.g. murram) road and smaller feeder roads linked to it. Nentanai does not 
have an all-weather road. A total of 64 individuals (90 missing responses) responded to the question on road maintenance. Thirty four indicated that roads are maintained collectively, and that a committee organizes to fix roads and enable public transport vehicles access to the area. Only five total individuals suggested that the government or the Catholic Church are important actors in road maintenance. However, eight individuals believed that road maintenance is often conducted by politicians only during campaign periods.

\section{Focus Groups}

Pastoralists themselves are cognizant of the potential risks for producers associated with subdivision. The initial question posed at each focus group was "What are the most critical issues facing you, your livestock, and the environment in this place?" Subdivision was either mentioned first or second across all 14 focus groups. Economic diversification and herder efforts to crossbreed their animals (particularly zebu cattle) with improved breed Sahiwal and Boran animals were cited in either $2^{\text {nd }}$ or $3^{\text {rd }}$ position in each meeting. Two follow up questions regarding subdivision were asked: "What is the status of subdivision in your area" and "What do you think will be the effects of subdivision on your livestock and your families." All respondents confirmed that at this point they believe subdivision to be "unstoppable", and they were concerned that privatization would lead to less flexibility in the face of drought. The general perception was that subdivision would give people the security of a "title deed" (a positive); however, it could force a decrease in the numbers of livestock held by households. Conversely, it was the consensus at 10 focus groups that people would "continue to use their land communally" and that "leasing arrangements would have to occur" because the area was "too dry". 
Also, on the positive side, subdivision would allow herders to enforce boundaries between their herds, and this could contribute to herders' ability to control the process of crossbreeding their animals, something that is very difficult given that herds mix regularly while grazing on communal rangelands. This perception does indicate that herders expect boundaries between parcels to be enforced to some degree. Interestingly, both economic diversification and crossbreeding were often mentioned in association with subdivision. The shared view was that it had already become difficult for a household to get by dependent only on their animals, and, when subdivision occurs, a purely pastoral lifestyle definitely would be insufficient. Therefore, herders voiced that 1) diversifying their economic efforts into other activities such as agriculture, wage labor, business or investment property would be important, and 2) breeding larger crossbred animals that produce more meat and milk, and garner more in the marketplace (characteristics borne out by research as well, see Trail and Gregory 1981, Cunningham and Syrstad 1987, Rutten 1992) would allow herders to reap more benefits from the animals they were able to keep on their private parcels. However, herders were also keenly aware that there were tradeoffs associated with having too many crossbred animals that "do not walk well, need more forage than [our] zebu cows, and are like children (i.e. needing to be picked up) when there is drought" (Focus group \#14, Eselenkei group ranch, parenthetic material ours). Education was spoken of often as a sort of "long term" diversification effort - as educated children would have more options than their parents.

These comments suggest that pastoral households are actively pursuing (or are expecting to pursue) a range of coping strategies in response to subdivision and expected limitations on livestock mobility. Economic diversification and intensification of livestock production strategies are actions that households perceive will mitigate the impacts of subdivision. Leasing 
and continuing to use subdivided parcels communally to some degree also were cited as potential coping mechanisms. Again, these comments emphasize that mobility continues to be a serious concern for households in a post-subdivision environment in spite of ongoing changes in production strategies.

Thus some collective action with respect to the provision of public goods continues to occur within the group ranches, even after subdivision. These efforts are largely initiated and sustained without external support.

\section{DISCUSSION}

Results of the NDVI analyses indicate that the impact of subdivision on household access to forage differs dramatically depending on group ranch membership and upon where an individual parcel is located within any one group ranch. We see that parcel sharing does translate into more grazing flexibility, particularly when it occurs between households in different locations. Previous modelling analyses in Kajiado group ranches also emphasize the critical poverty mitigation role that parcel sharing mechanisms would play in a post-subdivision environment, even as the economic strategies of pastoral households diversify and change (Thornton et al. 2005, Boone et al. 2005). This is important given the significant levels of economic diversification present on all group ranches, although it is clear that livestock still play a vital role in Maasai livelihood strategies.

Our results indicate that "sharing" in a post-subdivision environment take many forms; whether based on redistribution, agreements, pasture swapping, or leasing of pastures based on mechanisms of economic exchange. Over 72 percent of households in subdivided Meto, Enkaroni, and Nentanai, and 75 percent of Osilalei herders in a drought year either were mobile, 
or planned to move their livestock within or beyond group ranch boundaries using sharing, swapping or leasing mechanisms. Individuals are also organizing around water and infrastructure provision, both critical elements for the maintenance of Maasai livestock enterprise. These results emphasize the underlying ecological and institutional logic of postsubdivision collective arrangements that link households together spatially in a process of pasture management.

Interestingly, the most commonly used sharing/swapping mechanisms are those that are based on pre-existing social relationships and norms, e.g. familial ties or friendships. New economic norms of pasture leasing are present, but at this time they are not the dominant mechanism of maintaining mobility and access in the post-subdivision environment. Previous research suggests that land tenure and economic changes would challenge the ongoing viability and strength of social and cultural ties in pastoral societies (Kituyi 1990, Ensminger 1991); however, the widespread emergence of sharing mechanisms questions the inevitability of these assertions. Those pursuing collective strategies do so both for economic expediency and for productive reasons - in an effort to access additional forage resources and re-create access to a full compliment of pasture types. Yet, not all herders are engaging in sharing/swapping of livestock. While logic suggests that poor households with fewer animals and less grazing pressure in their parcels would have the potential to gain economically from leasing out pastures to richer producers, there are indications that herders perceive that richer pastoralists benefit disproportionately from these arrangements. Pastoral households are actively engaged in assessing the positive and negative tradeoffs associated with both subdivision and sharing/swapping/leasing strategies. Results from the series of focus groups carried out in 2005 
indicate that similar evaluation is taking place in the Amboseli group ranches prior to subdivision.

We identified some initial characteristics of households who use re-aggregation strategies. Our expectation that those who must share or redistribute have larger livestock numbers was supported. However, actual size of a household parcel does not seem to affect whether a household is mobile. TLUs were also correlated with movement of sedentary households in Imbirikani, a result which highlights some of the potential tradeoffs linked with pastoral diversification into agricultural activities. Agricultural activities are sedentary, but sedentarization in areas with high population density imply limitations on forage availability for households able to maintain large herds.

Given the pace and extent of socio-economic and land tenure change occurring in Kajiado specifically, but also pastoral systems globally, pastoral households are facing both significant opportunities and risks in their productive environment (Blench 2001, Thornton et al. 2003). There are examples from agrosylvicultural and other pastoral systems in which traditional resource management mores combined with new land tenure and economic conditions and innovative land use strategies emerge (Pinkerton 1998, Banks et al. 2002, Curtin et al. 2003). However, Thornton et al. (2003) describe opportunities for poverty reduction in pastoral areas as conditional on other circumstances, in which livelihoods could improve if market integration increases, if economic diversification occurs, and if social capital mechanisms and systems remain intact. Conversely, risk and vulnerability of pastoral populations would rise if social capital declines, if herders lose flexibility to respond to ecological variability, and if market integration remains low. 
The efforts of Kajiado pastoralists to remain mobile in a post-subdivision environment is the type of strategy described above that potentially puts pastoralists on the "opportunity" side of the sustainable livelihoods equation. We have seen that the collective action mechanisms emerging in Kajiado are grounded within traditional social networking mores, and new economic innovation also characterizes these strategies. The potential effect of these strategies could be to maintain pastoral flexibility in the face of ongoing drought conditions and ecological variability. Efforts of Kajiado pastoralists to diversify their economic strategies is ongoing; however, the reaggregation efforts by Maasai pastoralists on the ground should also mitigate the costs associated with subdivision and contribute to more secure livelihoods for pastoral households in the face of great change. There is, however, a role for policy makers to play in creating a supportive policy environment in which these efforts can evolve over time.

Because Maasai continue to develop and finance collective structures for the provision and maintenance of boreholes, earthen dams, schools and health clinics, it demonstrates the critical nature of these goods and services for the livestock enterprise and for overall wellbeing. There is a strong case for encouraging and strengthening partnerships between Maasai themselves, the public sector and relevant NGOs in order to enhance the levels and quality of these services and to reduce the general impacts of risk.

\section{Policy Implications}

The dual goals of land tenure reform and poverty reduction remain high on the agenda of African governments. The African Union and its partners are engaged in designing a policy framework for land tenure in Africa aimed at enhancing the tenure security of marginalized groups (including pastoralists) as part of a broader strategy for achieving poverty reduction, gender equity, sustainability, and efficiency. Because this effort involves consultation at national 
and sub-regional levels, it provides a possible platform for communicating the urgency of land tenure issues in pastoral areas. The emergent re-aggregation efforts of pastoralists themselves are an example of coping strategies that should be taken into account during this consultative process.

We suggest that:

- Dominant policy and research narratives assuming that mobile pastoralism is economically irrational or a relic of the past, and that privatization signals the imminent demise of pastoralism as a livelihood strategy, can be revised given that collective action strategies are emerging.

- Policy makers should be aware that the drive to subdivide among pastoral households arises largely from the perceived need to defend land against external (in-migration) and internal (land grabbing) threats - and not from an innate agreement on the part of pastoralists with the premises and implications of owning individual property. The fact that parcel re-aggregation is occurring provides a strong case for subdivision as a defensive strategy, because, once subdivided and theoretically secured, individuals revert to joint pasture use and management strategies, though at scales smaller than group ranches. There is thus a critical need for policy to recognize group or collective rights, providing them the same measure of protection as it does private, individual rights, especially in circumstances where groups and collectivities continue to use and prefer such arrangements.

- In spite of privatization, the ecological exigencies of the semi-arid to arid pastoral environment have not changed. We see that pastoral households in a post-subdivision environment are seeking ways to enhance the viability of their production system through re-aggregation mechanisms. However, negotiating mobility in this context could become more difficult. For example, negotiating access from an unsubdivided area (e.g. the Amboseli group ranches) into a subdivided zone (e.g. Ilmatapato or Ilkaputei Sections) during drought would be more difficult and could occur only on an individual, herder to herder basis. This implies that the effort to be mobile will be more "labor intensive," but suggests again that social relationships (e.g. those based on clan membership, stock associations, and marriage connections) between herders could become more, not less, important as the process of subdivision proceeds. A policy dialogue between land managers and herders that is supportive of mechanisms to maintain mobility in this setting will be crucial.

- Quite clearly, group ranch subdivision does not preclude individuals from seeking common solutions to shared problems, though it may make it more difficult. Jointly used resources such as boreholes, dams, roads and schools continue to be maintained collectively through cash or in-kind contributions. Similarly, groups of men and women continue to pursue collective welfare-enhancing ventures in livestock sales and 
marketing, posho-milling, rotating savings/groups, etc. There is wide scope for actors in both government and non-government agencies to explore innovative measures to enhance collective action.

The results presented here are preliminary, but they are important. They establish a basis and direction for more nuanced research. There are gaps in our knowledge surrounding these aggregation strategies. How are re-aggregation decisions made, and who is using these sharing mechanisms? What is the interaction between livelihood diversification efforts and the need to remain mobile? Are undiversified households facing greater risk in a post-subdivision environment and, therefore, are more likely to engage in re-aggregation strategies? The relative contributions of collective activities to household incomes and welfare should also be established and constraints to post-subdivision collective action be better understood. Our knowledge is lacking on details of timing, duration, and the proportion of livestock herds that are distributed and shared when re-aggregation occurs. The efficacy of pasture sharing mechanisms to increase access to forage and contribute to livestock productivity is also unquantified, although our assumption is that the practice must confer some advantage post-subdivision given that the large proportion of herders engaged in these strategies. Are pasture sharing mechanisms a fully substitutable strategy for the losses in mobility implied by subdivision, or is it a poor second choice with potentially high transaction costs for herding households?

East African governments are not the only ones grappling with land tenure issues in complex settings at the intersection of culture, ecology, and economy. Governments in Asia, North and West Africa, and the Middle East are confronted with similar problems of balancing property rights, cultural continuity, economic sustainability, and ecological viability in pastoral systems. It is interesting to note that the issues being discussed globally are remarkably similar to the debates surrounding privatization and communal lands which led to the early formation of 
Kajiado group ranches in the 1960s and 1970s. Thus, the on-the-ground efforts of Kajiado pastoralists to reinstitute mobility and maintain flexibility in the face of subdivision may speak to the ability of Maasai pastoralists, as well as other pastoral groups, to adjust pro-actively to changing political and economic realities. 


\section{REFERENCES}

Agrawal, A. 2002. Common resources and institutional sustainability. In The drama of the Commons, ed. E. Ostrom, T. Dietz, N. Dolsaket al. Washington, D.C.: National Academy Press.

Baland, J-M, and J-P. Platteau. 2000. Halting degradation of natural resources: Is there a role for rural communities? Oxford: Oxford University Press.

Banks, T., C. Richard, L. Ping and Y. Zhaoli. 2003. Community-based grassland management in Western China. Mountain Research and Development 23 (2): 132-140.

Bekure, S., P. N. de Leeuw, et al. ed. 1991. Maasai herding: An analysis of the livestock production system of Maasai pastoralists in Eastern Kajiado District, Kenya. ILCA Systems Study 4. Addis Ababa, Ethiopia: International Livestock Center for Africa.

Blench, R. 2001. 'You can't go home again': Pastoralism in the new millennium. London: Overseas Development Institute.

Boone, R.B., S.B. BurnSilver, P.K. Thornton, J.S. Worden, and K.A. Galvin. 2005. Quantifying declines in livestock due to land subdivision in Kajiado District, Kenya. Rangeland ecology and management. Journal of Rangeland Ecological Management 58: 523-532.

Boone, R.B. and N.T. Hobbs. 2004. Lines around fragments: effects of fencing on large herbivores. African Journal of Range \& Forage Science 21(3):147-158

BurnSilver, S.B. 2005. ILRI Focus Groups in four maasai group ranches, Ereto O Ereto Project. Nairobi Kenya: International Livestock Research Institute.

BurnSilver, S. B. 2007. Economic Pathways of Change and Continuity: Maasai Livelihoods and Movement Patterns in a Fragmenting System, Kajiado District, Kenya. Graduate Degree Program in Ecology. PhD. Fort Collins, Colorado State University.

Cunningham, E.P. and O. Syrstad. 1987. Crossbreeding Bos taurus and Bos indicus cattle for milk production in the tropics. Animal Production and Health Paper 68. Rome: Food and Agriculture Organization.

Curtin, C.G., N.F. Sayre and B.D. Lane. 2002. Transformations of the Chihuahuan borderlands: Grazing, fragmentation, and biodiversity conservation in desert grasslands. Environmental Science and Technology 5:55-68.

Demsetz, H. 1967. Toward a theory of property rights. American Economic Review 62:347-359.

Doherty, D.A. 1987. Maasai pastoral potential: A study of ranching in Narok District, Kenya. Unpublished Ph.D dissertation. Department of Anthropology, McGill University. 
Ellis, J., N. Hobbs, et al. 2001. Biocomplexity, spatial scale and fragmentation: Implications for arid and semi-arid ecosystems. Arlington, Va.: National Science Foundation.

Ellis, J. and D. Swift. 1988. Stability of African pastoral ecosystems: Alternate paradigms and implications for development. Journal of Range Management 41(6): 450-459.

Ensminger, J. and A. Rutten. 1991. The political economy of changing property rights: Dismantling a pastoral Commons. American Ethnologist 18 (4): 683-699.

ETC East Africa. 1998. Framework for Natural Resources Use and Management. Arid and Semi-Arid Lands Program, Kajiado District. Final Report.

FAO. 2002. Improved animal health for poverty reduction and sustainable livelihoods. FAO Animal Production and Health Paper no. 153. Rome: Food and Agriculture Organization of the United Nations.

Fratkin, E. and R. Mearns. 2003. Sustainability and pastoral livelihoods: Lessons from East African Maasai and Mongolia. Human Organization 62(2): 112-122.

Galaty, J. G. 1999. Grounding pastoralists: Law, politics and dispossession in East Africa.” Nomadic Peoples 3(2):56-73.

Galaty, J. G. 1994a. Ha(1)ving land in Common: The subdivision of Maasai group ranches in Kenya." Nomadic Peoples 34/35:109-121.

Galaty, J.G. 1994b. The pastoralist's dilemma: Common property and enclosure in Kenya's rangeland. In Food systems under stress in Africa: African-Canadian Research Cooperation, ed. R.Vernooy and K.M. Kealey. Ottawa, Canada: IDRC.

Galaty, 1993. Maasai expansion and the New East African Pastoralism. In Being Maasai: Ethnicity and identity in East Africa, ed. T. T. Spear and R. Waller. London: J. Currey; Dar es Salaam: Mkuki na Nyota; Nairobi: EAEP; Athens: Ohio University Press.

Galaty, J. G. 1992. Social and economic factors in the privatization, sub-division and sale of Maasai Ranches." Nomadic Peoples 30: 26-40.

Galaty, J. G. and D. L. Johnson. 1990. Introduction: Pastoral systems in global perspective. In The world of pastoralism: Herding systems in comparative perspective, ed. J. G. Galaty and D. L. Johnson. New York: The Guilford Press.

Galvin, K. A., R. B. Boone, et al. 2001. Impacts of climate variability on East African pastoralists: Linking social science and remote sensing. Climate Research 19: 161-172.

Grandin, B.E.1987. East African pastoral land tenure: Some reflections from Maasailand. In Land, trees and tenure, ed. John B. Raintree. Proceedinsg of Tenure Issues in Agroforestry International Workshop. May 27-31, 1987, Nairobi. Nairobi and Madison, Wi.: ICRAF and the Land Tenure Center. 
Hardin, G. 1968. The tragedy of the Commons. Science 162 (December 13): 1243-1248.

Illius, A. W. and T. G. O'Connor. 2000. Resource heterogeneity and ungulate population dynamics." OIKOS 89: 283-294.

Kimani, K. and Pickard, J.1998. Recent trends and implications of group ranch subdivision and fragmentation in Kajiado District, Kenya. The Geographic Journal 164 (2): 202-213.

Kipury N. 1989. Maasai women in transition: Class and gender in the transformation of a pastoral society.” Unpublished Ph.D. Dissertation, Temple University.

Kituyi, M. 1990. Becoming Kenyans: Socio-economictransformation of the pastoral Maasai. Nairobi: African Center for Technology Studies Press.

Lane, C. and R. Moorehead. 1994. New thinking on pastoral resource tenure in dryland Africa. London: International Institute for Environment and Development.

Leonard, D.K. 2003. The new institutional economics and the restructuring of animal health services in Africa. In Africa's changing markets for health and veterinary services: The new institutional issues. UCIAS Edited Volume 5. Accessed May 2006:

http://repositories.cdlib.org/cgi/viewcontent.cgi?article=1062\&context=uciaspubs/editedvolumes.

Little, P., Smith K., Cellarius, B. A., Coppock, D. L.and C. B. Barrett. 2001. Avoiding disaster: Diversification and risk management among East African herders. Development and Change 32: 387-419.

Meinzen-Dick, R., L. Brown, H., Feldstein and A., Quisumbing. 1997. Gender, property rights and natural resources. World Development 25(8):1305-1315.

Munei, K. 1987. Grazing schemes and group ranches as models for developing pastoral lands in Kenya. In: Property, poverty and people: Changing rights in property and problems of pastoral development, eds. P.T.W., Baxter and R., Hogg. Department of Social Anthropology and International Development. Manchester, England: University of Manchester.

Mwangi, E. N. 2003. Institutional change and politics: The transformation of property rights in Kenya's Maasailand, Indiana University. PhD Dissertation.

Mwangi, E.N. 2005. The transformation of property rights in Kenya's Maasailand: Triggers and motivations. CAPRi Working Paper No. 35. Washington D.C.: International Food Policy Research Institute.

Mwangi, E.N. 2006a. Subdividing the Commons: The politics of property rights transformation in Kenya's Maasailand. CAPRi Working Paper No. 46. Washington D.C.: International Food Policy Research Institute.

Mwangi, E.N. 2006b. The footprints of history: Path dependence in the transformation of property rights in Kenya's Maasailand. Journal of Institutional Economics 2 (2): 1-23 
Niamir-Fuller, M. 1999. Managing mobility in African rangelands: The legitimization of transhumance. London: Intermediate Technology Publications.

Ostrom, E. 2005. Understanding institutional diversity. Princeton, NJ: Princeton University Press.

Ostrom, E. 1990. Governing the Commons: The evolution of institutions for collective action. New York: Cambridge University Press.

Ostrom, E., J. Burger, et al. 1999. Revisiting the Commons: Local lessons, global challenges. Science 284: 278-282.

Ostrom, E., and Schlager, E. 1996. The formation of property rights. In Rights to nature: Ecological, economic, cultural, and political principles of institutions for the environment, ed. S. Hanna, C. Folke, and K-G. Mäler. Washington, D.C.: Island Press.

Ostrom, E., Stern, P.C., Dietz, T., Weber, E.U., Dolsak, N. and Stonich, S., ed. 2002. The drama of the Commons. Washington D.C: National Academy Press.

Reid, R., P. Thornton, et al. 2003. Loss and fragmentation of habitat for pastoral people and wildlife in East Africa: Concepts and issues. Rangelands in the New Millenium, VII Durban, South Africa: International Rangelands Congress.

Rutten, M. M. E. M. 1992. Selling wealth to buy poverty: the process of the individualization of land ownership among the Maasai pastoralists of Kajiado District, Kenya, 1890-1990. Fort Lauderdale, Fl: Verlag Breitenbach Publishers, Saarbrücken.

Schlager, E. and Ostrom, E. 1992. Property-rights regimes and natural resources: A conceptual analysis. Land Economics 68 (3): 249-62.

Thornton, P.K., Kruska, R.L., Henninger, N., Kristjanson, P.M., Reid, R.S., Atieno, F., Odero, A.N., and T. Ndegwa. 2003. Mapping poverty and livestock in the developing world. Report Commissioned by the Department for International Development- UK. International Livestock Research Institute. Nairobi, Kenya. 117 p.

Thornton, P. K., S. B. BurnSilver, and K.A. Galvin. 2006. Modelling the impacts of group ranch subdivision on agro-pastoral households in Kajiado, Kenya. Agricultural Systems 87: 331-356.

Trail, J.C.M. and K.E. Gregory. 1981. Sahiwal cattle: An evaluation of their potential contribution to milk and beef production in Africa. International Livestock Centre for Africa, Addis Ababa, Ethiopia.

Turner, M. D. 1999. The role of social networks, indefinite boundaries and political bargaining in maintaining the ecological and economic resilience of the transhumance systems of Sudano-Sahelian West Africa. In Managing mobility in African rangelands: The legitimization of transhumance, ed. M. Niamir-Fuller. London: Intermediate Technology Publications Ltd. 
VITO. 2002. VEGETATION home page and catalogue. http://www.vgt.vito.be/indexstart.htm

Zaal, F. 1999. Economic integration in pastoral areas: Commercialisation and social change among Kenya's Maasai. Nomadic Peoples 3(2): 97-115. 


\section{List of CAPRi Working Papers}

01 Property Rights, Collective Action and Technologies for Natural Resource Management: A Conceptual Framework, by Anna Knox, Ruth Meinzen-Dick, and Peter Hazell, October 1998.

02 Assessing the Relationships between Property Rights and Technology Adoption in Smallholder Agriculture: A Review of Issues and Empirical Methods, by Frank Place and Brent Swallow, April 2000.

03 Impact of Land Tenure and Socioeconomic Factors on Mountain Terrace Maintenance in Yemen, by A. Aw-Hassan, M. Alsanabani and A. Bamatraf, July 2000.

04 Land Tenurial Systems and the Adoption of a Mucuna Planted Fallow in the Derived Savannas of West Africa, by Victor M. Manyong and Victorin A. Houndékon, July 2000 .

05 Collective Action in Space: Assessing How Collective Action Varies Across an African Landscape, by Brent M. Swallow, Justine Wangila, Woudyalew Mulatu, Onyango Okello, and Nancy McCarthy, July 2000.

06 Land Tenure and the Adoption of Agricultural Technology in Haiti, by Glenn R. Smucker, T. Anderson White, and Michael Bannister, October 2000.

07 Collective Action in Ant Control, by Helle Munk Ravnborg, Ana Milena de la Cruz, María Del Pilar Guerrero, and Olaf Westermann, October 2000.

08 CAPRi Technical Workshop on Watershed Management Institutions: A Summary Paper, by Anna Knox and Subodh Gupta, October 2000.

09 The Role of Tenure in the Management of Trees at the Community Level: Theoretical and Empirical Analyses from Uganda and Malawi, by Frank Place and Keijiro Otsuka November 2000.

10 Collective Action and the Intensification of Cattle-Feeding Techniques a Village Case Study in Kenya's Coast Province, by Kimberly Swallow, November 2000.

11 Collective Action, Property Rights, and Devolution of Natural Resource Management: Exchange of Knowledge and Implications for Policy, by Anna Knox and Ruth MeinzenDick, January 2001. 
12 Land Dispute Resolution in Mozambique: Evidence and Institutions of Agroforestry Technology Adoption, by John Unruh, January 2001.

13 Between Market Failure, Policy Failure, and "Community Failure": Property Rights, Crop-Livestock Conflicts and the Adoption of Sustainable Land Use Practices in the Dry Area of Sri Lanka, by Regina Birner and Hasantha Gunaweera, March 2001.

14 Land Inheritance and Schooling in Matrilineal Societies: Evidence from Sumatra, by Agnes Quisumbing and Keijuro Otsuka, May 2001.

15 Tribes, State, and Technology Adoption in Arid Land Management, Syria, by Rae, J, Arab, G., Nordblom, T., Jani, K., and Gintzburger, G., June 2001.

16 The Effects of Scales, Flows, and Filters on Property Rights and Collective Action in Watershed Management, by Brent M. Swallow, Dennis P. Garrity, and Meine van Noordwijk, July 2001.

17 Evaluating Watershed Management Projects, by John Kerr and Kimberly Chung, August 2001.

18 Rethinking Rehabilitation: Socio-Ecology of Tanks and Water Harvesting in Rajasthan, North-West India, by Tushaar Shah and K.V.Raju, September 2001.

19 User Participation in Watershed Management and Research, by Nancy Johnson, Helle Munk Ravnborg, Olaf Westermann, and Kirsten Probst, September 2001.

20 Collective Action for Water Harvesting Irrigation in the Lerman-Chapala Basin, Mexico, by Christopher A. Scott and Paul Silva-Ochoa, October 2001.

21 Land Redistribution, Tenure Insecurity, and Intensity of Production: A Study of Farm Households in Southern Ethiopia, by Stein Holden and Hailu Yohannes, October 2001.

22 Legal Pluralism and Dynamic Property Rights, by Ruth Meinzen-Dick and Rajendra Pradhan, January 2002.

23 International Conference on Policy and Institutional Options for the Management of Rangelands in Dry Areas, by Tidiane Ngaido, Nancy McCarthy, and Monica Di Gregorio, January 2002.

24 Climatic Variablity and Cooperation in Rangeland Management: A Case Study From Niger, by Nancy McCarthy and Jean-Paul Vanderlinden, September 2002. 
25 Assessing the Factors Underlying the Differences in Group Performance:

Methodological Issues and Empirical Findings from the Highlands of Central Kenya, by Frank Place, Gatarwa Kariuki, Justine Wangila, Patti Kristjanson, Adolf Makauki, and Jessica Ndubi, November 2002.

26 The Importance of Social Capital in Colombian Rural Agro-Enterprises, by Nancy Johnson, Ruth Suarez, and Mark Lundy, November 2002.

27 Cooperation, Collective Action and Natural Resources Management in Burkina Faso: A Methodological Note, by Nancy McCarthy, Céline Dutilly-Diané, and Boureima Drabo, December 2002.

28 Understanding, Measuring and Utilizing Social Capital: Clarifying Concepts and Presenting a Field Application from India, by Anirudh Krishna, January 2003.

29 In Pursuit Of Comparable Concepts and Data, about Collective Action, by Amy Poteete And Elinor Ostrom, March 2003.

30 Methods of Consensus Building for Community Based Fisheries Management in Bangladesh and the Mekong Delta, by Parvin Sultana and Paul Thompson, May 2003.

31 Formal and Informal Systems in Support of Farmer Management of Agrobiodiversity: Some Policy Challenges to Consolidate Lessons Learned, by Marie Byström, March 2004.

32 What Do People Bring Into the Game: Experiments in the Field About Cooperation in the Commons, by Juan-Camilo Cárdenas and Elinor Ostrom, June 2004.

33 Methods for Studying Collective Action in Rural Development, by Ruth Meinzen-Dick, Monica Di Gregorio, and Nancy McCarthy, July 2004.

34 The Relationship between Collective Action and Intensification of Livestock

Production: The Case of Northeastern Burkina Faso, by Nancy McCarthy, August 2004.

35 The Transformation of Property Rights in Kenya's Maasailand: Triggers and Motivations by Esther Mwangi, January 2005.

36 Farmers' Rights and Protection of Traditional Agricultural Knowledge, by Stephen B. Brush, January 2005.

37 Between Conservationism, Eco-Populism and Developmentalism - Discourses in Biodiversity Policy in Thailand and Indonesia, by Heidi Wittmer and Regina Birner, January 2005. 
38 Collective Action for the Conservation of On-Farm Genetic Diversity in a Center of Crop Diversity: An Assessment of the Role of Traditional Farmers' Networks, by Lone B. Badstue, Mauricio R. Bellon, Julien Berthaud, Alejandro Ramírez, Dagoberto Flores, Xóchitl Juárez, and Fabiola Ramírez, May 2005.

39 Institutional Innovations Towards Gender Equity in Agrobiodiversity Management: Collective Action in Kerala, South India,, by Martina Aruna Padmanabhan, June 2005.

40 The Voracious Appetites of Public versus Private Property: A View of Intellectual Property and Biodiversity from Legal Pluralism, by Melanie G. Wiber, July 2005.

41 Who Knows, Who Cares? Determinants of Enactment, Awareness and Compliance with Community Natural Resource Management Bylaws in Uganda, by Ephraim Nkonya, John Pender, Edward Kato, Samuel Mugarura, and James Muwonge, August 2005.

42 Localizing Demand and Supply of Environmental Services: Interactions with Property Rights, Collective Action and the Welfare of the Poor, by Brent Swallow, Ruth Meinzen-Dick, and Meine von Noordjwik, September 2005.

43 Initiatives for Rural Development through Collective Action: The Case of Household Participation in Group Activities in the Highlands of Central Kenya, By Gatarwa Kariuki and Frank Place, September 2005.

44 Are There Customary Rights to Plants? An Inquiry among the Baganda (Uganda), with Special Attention to Gender, by Patricia L. Howard and Gorettie Nabanoga, October 2005.

45 On Protecting Farmers' New Varieties: New Approaches to Rights on Collective Innovations in Plant Genetic Resources by Rene Salazar, Niels P. Louwaars, and Bert Visser, January 2006.

46 Subdividing the Commons: The Politics of Property Rights Transformation in Kenya's Maasailand, by Esther Mwangi, January 2006.

47 Biting the Bullet: How to Secure Access to Drylands Resources for Multiple Users, by Esther Mwangi and Stephan Dohrn, January 2006.

48 Property Rights and the Management of Animal Genetic Resources, by Simon Anderson and Roberta Centonze, February 2006. 
49 From the Conservation of Genetic Diversity to the Promotion of Quality Foodstuff: Can the French Model of 'Appellation d'Origine Contrôlée' be Exported? by Valérie Boisvert, April 2006.

50 Facilitating Collective Action and Enhancing Local Knowledge: A Herbal Medicine Case Study in Talaandig Communities, Philippines, by Herlina Hartanto and Cecil Valmores, April 2006.

51 Water, Women and Local Social Organization in the Western Kenya Highlands, by Elizabeth Were, Brent Swallow, and Jessica Roy, July 2006.

52 The Many Meanings of Collective Action: Lessons on Enhancing Gender Inclusion and Equity in Watershed Management, by Laura German, Hailemichael Taye, Sarah Charamila, Tesema Tolera, and Joseph Tanui, July 2006.

53 Decentralization and Environmental Conservation: Gender Effects from Participation in Joint Forest Management, by Arun Agrawal, Gautam Yadama, Raul Andrade, and Ajoy Bhattacharya, July 2006.

54 Improving the Effectiveness of Collective Action: Sharing Experiences from Community Forestry in Nepal, by Krishna P. Achyara and Popular Gentle, July 2006.

55 Groups, Networks, and Social Capital in the Philippine Communities, by Marie Godquin and Agnes R. Quisumbing, October 2006.

56 Collective Action in Plant Genetic Resources Management: Gendered Rules of Reputation, Trust and Reciprocity in Kerala, India, by Martina Aruna Padmanabhan, October 2006.

57 Gender and Local Floodplain Management Institutions--A case study from Bangladesh, by Parvin Sultana and Paul Thompson, October 2006.

58 Gender Differences in Mobilization for Collective Action: Case Studies of Villages in Northern Nigeria, by Saratu Abdulwahid, October 2006.

59 Gender, Social Capital and Information Exchange in Rural Uganda, by Enid Katungi, Svetlana Edmeades, and Melinda Smale, October 2006.

60 Rural Institutions and Producer Organizations in Imperfect Markets: Experiences from Producer Marketing Groups in Semi-Arid Eastern Kenya, by Bekele Shiferaw, Gideon Obare and Geoffrey Muricho, November 2006. 
61 Women's Collective Action and Sustainable Water Management: Case of SEWA's Water Campaign in Gujarat, India, by Smita Mishra Panda, October 2006.

62 Could Payments for Environmental Services Improve Rangeland Management inCentral Asia, West Asia and North Africa? by Celine Dutilly-Diane, Nancy McCarthy, Francis Turkelboom, Adriana Bruggeman, James Tiedemann, Kenneth Street and Gianluca Serra, January 2007.

63 Empowerment through Technology: Gender Dimensions of Social Capital Build-Up in Maharashtra, India, by Ravula Padmaja and Cynthia Bantilan, February 2007.

64 Gender and Collective Action: A Conceptual Framework for Analysis, by Lauren Pandolfelli, Ruth Meinzen-Dick, and Stephan Dohrn, May 2007.

65 Gender, Wealth, and Participation in Community Groups in Meru Central District, Kenya, by Kristin E. Davis and Martha Negash, May 2007. 